\title{
Monitoring Macan Tutul Jawa (Panthera pardus melas Cuvier, 1809) dengan Kamera Trap di Cagar Alam Nusakambangan Timur Kabupaten Cilacap, Provinsi Jawa Tengah
}

\author{
Budi Santoso $^{1 *}$, Wahyono Restanto ${ }^{2}$ \\ 1,2 Balai Konservasi Sumber Daya Alam Jawa Tengah
}

\begin{abstract}
Monitoring of the existence of the Javan Leopard (Panthera pardus melas) in the Nusakambangan Timur Nature Reserve, Cilacap Regency, has been carried out in July-November 2020. Monitoring is carried out using the method of collecting signs of animal presence and installing camera traps. Photos / videos caught on camera traps are counted on the encounter rate. The monitoring results obtained 97 videos which were divided into 6 videos of P.p. melas, 15 videos of wild boar (Sus scrofa), 1 video of mouse deer (Tragulus javanicus), 2 videos of mountain squirrels (Tupaia montana), 1 video of mice (Apodemus sp.) 20 videos of human activities, and 47 videos of non detection. The result of the Encounter Rate calculation shows the result of P.p. melas 4.44 / 100 days; wild boar 11.85 / 100 days; Squirrels 1.48 / 100 days; rats and mouse deer 0.74 / 100 days, respectively. Meanwhile, for the trail of P.p. melas found 2 impurities.
\end{abstract}

Keywords: Javan Leopard; Nature Reserve; Nusakambangan Timur.

\begin{abstract}
Abstrak
Telah dilakukan monitoring keberadaan Macan Tutul Jawa (Panthera pardus melas) di kawasan cagar alam Nusakambangan Timur Kabupaten Cilacap pada bulan Juli-November 2020. Monitoring dilakukan dengan menggunakan metode pengumpulan tanda-tanda keberadaan satwa dan pemasangan camera trap. Foto/video yang tertangkap kamera dihitung tingkat perjumpaannya. Hasil monitoring didapatkan 97 video yang terbagi dalam 6 video P.p. melas, 15 video Babi hutan (Sus scrofa), 1 video Kancil (Tragulus javanicus), 2 video Tupai gunung (Tupaia montana), 1 video Tikus (Apodemus sp.) 20 video aktivitas manusia, dan 47 video non detection. Hasil perhitungan Encounter Rate menunjukkan hasil P.p. melas 4,44/100 hari; babi hutan 11,85/100 hari; Tupai 1,48/100 hari; tikus dan kancil masing-masing 0,74/100 hari. Sementara itu untuk jejak keberadaan P.p. melas ditemukan 2 kotoran.
\end{abstract}

Kata kunci: Cagar Alam; Macan Tutul Jawa; Nusakambangan Timur.

\footnotetext{
* Corresponding Author: Budi Santoso, email: budissi@yahoo.com, Balai Konservasi Sumber Daya Alam Jawa Tengah Jl. Dr. Suratmo No. 171 semarang

Copyright (C) 2021 Al-Hayat: Journal of Biology and Apllied Biology
} 


\section{Pendahuluan}

Macan tutul jawa merupakan karnivora besar yang masih tersisa di pulau Jawa setelah harimau jawa (Panthera tigris sondaica) pada tahun 1980-an. Meskipun jumlahnya di habitat ex situ cukup banyak namun populasinya di habitat in situ semakin mengkhawatirkan.

Panthera pardus secara global dalam kategori Vulnerable (VU) The IUCN Red List of Threatened Species dan masuk Apendiks I CITES (Stein et al., 2016), (Maharadatunkamsi et al., 2020), namun secara spesifik P.p. melas masuk dalam kategori Critically Endangered (CR) / kritis (Stein et al, 2016). Macan tutul jawa secara genetik memang berbeda dengan macan tutul lain yang hidup di benua Asia, dan diperkirakan hidup di Pulau Jawa sejak pertengahan zaman Pleistosen (Wilting et al., 2016). Di Indonesia, satwa ini dilindungi Undang-Undang No. 5/1990 dan Peraturan Pemerintah No. 7/1999 serta Peraturan Menteri Lingkungan Hidup dan Kehutanan No. P.106/ Menlhk/ Setjen/ Kum.1/ 12/2018.

Jumlah P.p. melas yang tersisa di alam liar belum diketahui secara pasti, namun diperkirakan terus berkurang akibat penyusutan hutan alam, berkurangnya satwa mangsa, dan aktivitas perburuan liar. Data mengenai P.p. melas yang ada hanya berdasarkan asumsi tentang kepadatannya dalam suatu wilayah.

Keberadaan P.p. melas paling tidak telah terdeteksi pada 12 area konservasi, taman nasional, cagar alam, hutan wisata, dan taman buru. Berdasarkan riset menggunakan perangkap kamera, diketahui kepadatan relatif P.p. melas di sejumlah taman nasional. Data tangkapan kamera tersebut menunjukkan bahwa, diperkirakan populasi P.p. melas di seluruh pulau Jawa saat ini antara 491-596 ekor (Kementerian LHK, 2016).

Di Jawa Barat, P.p. melas menempati posisi istimewa. Sejak 2005, satwa ini dijadikan identitas fauna setempat. Namun posisi istimewa belum menjadikan perhatian para pihak terhadap P.p. melas meningkat, data sebaran P.p. melas belum terpetakan dengan baik sehingga peta perlindungan dan konservasi habitatnya belum dilakukan maksimal. Meskipun demikian potensi kesesuaian habitat P.p. melas di Pulau Jawa mencapai luasan $1,159,864$ ha atau $8.9 \%$ dari total luasan pulau (Wibisono et al., 2018).

Kurangnya data, rusaknya habitat, dan makin maraknya konflik antara P.p. melas dengan manusia menuntut segera dilakukannya upaya konservasi yang terintegrasi dan kolaboratif antara Pemerintah Pusat, Pemerintah Daerah, Akademisi, LSM, perusahaan, media, dan pemerhati P.p. melas lainnya. Meskipun Macan Tutul Jawa merupakan satwa liar yang mampu menyes uaikan diri terhadap aktivitas manusia (Kusmawanto \& Imron, 2018), kita tentunya tidak ingin P.p. melas mengalami nasib serupa dengan kucing besar lainnya, Harimau Jawa dan Harimau Bali, yang kini tinggal nama. Kegiatan Monitoring tumbuhan dan satwa liar berupa kegiatan monitoring P.p. melas di Cagar Alam Nusakambangan Timur Kabupaten Cilacap (gambar 1). Kegiatan ini dilaksanakan sebagai upaya pelestarian P.p melas. Selain itu kegiatan ini merupakan langkah BKSDA Jateng (Balai Konservasi Sumber Daya Alam Jawa Tengah) dalam menindaklanjuti kegiatan peningkatan spesies prioritas terancam punah dimana P.p. melas termasuk salah satu di dalamnya. 25 Satwa Prioritas Terancam Punah ditetapkan sesuai Surat Keputusan Direktur Jenderal KSDAE No. 180/IVKKH/2015. 


\section{Gambar 1}

\section{Lokasi Monitoring P.p. melas Cagar Alam Nusakambangan Timur}

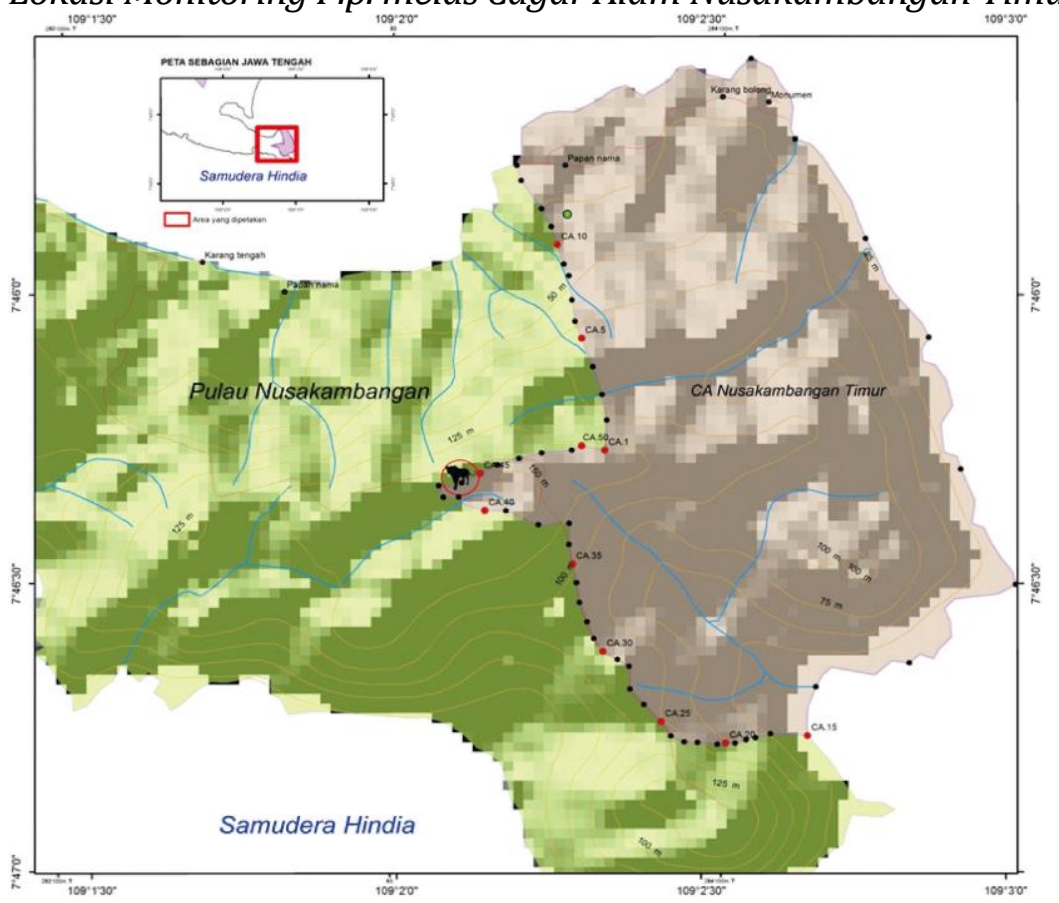

Tujuan penelitian ini adalah untuk memonitor keberadaan P.p. melas yang ada di Cagar Alam Nusakambangan Timur sehingga dapat diperoleh data up to date P.p. melas di kawasan tersebut.

\section{Metode Penelitian}

Kegiatan monitoring ini menggunakan metode pengumpulan tanda-tanda keberadaan satwa (jejak, cakaran, kotoran) dan metode camera trap. Pengumpulan data meliputi: (a) Orientasi lapang, untuk penentuan lokasi pengamatan sekaligus memasang camera trap. Untuk pemasangan camera trap dilakukan pada tanggal 7 Juli 2020 atau pemanenan dilakukan pada umur 135 hari. (b) pengumpulan informasi melalui pustaka terkait tentang Macan tutul jawa (P.p. melas) dan habitatnya, dan (c) Pengamatan lapangan ini akan mencatat beberapa hal antara lain jenis vegetasi yang ada di sepanjang transek pengamatan, sumber air tawar yang berpotensi menjadi air minum satwa termasuk P.p. melas, satwa mangsa yang ditemukan baik secara langsung maupun tidak langsung dan Jejak kaki, jejak cakar dan kotoran yang ditinggalkan.

Monitoring ini menggunakan 1 kamera, yang ditempatkan di lokasi dimana diperkirakan menjadi areal jelajah P.p. melas di Cagar alam Nusakambangan Timur (gambar 1). Pengamatan dilakukan pada P.p.melas serta satwa liar lain yang tertangkap oleh kamera selama pengamatan. Setelah diatur waktu, mode perekaman dan resolusi gambar kemudian camera trap dipasang pada batang pohon dengan posisi lurus dan ketinggian 40-45 cm dari permukaan tanah. Kamera diarahkan pada posisi jalur yang diduga menjadi perlintasannya. Untuk mengamankan kamera dapat dipasang rantai atau tali pengikat (O'Connell et al., 2011). Peralatan yang akan digunakan dalam kegiatan ini antara lain adalah sebagai berikut; alat tulis, 
peta kerja, kamera, handycam, binokuler, GPS, parang / golok, kamera trap.

Encounter rate (ER) P.p. melas dan satwa lain yang tertangkap kamera dihitung dari jumlah total semua foto, dibagi dengan hari aktif pemasangan kamera aktif dikalikan dengan 100 (jumlah foto dalam satuan 100 hari). Nilai 100 hari pada tingkat perjumpaan ini merupakan kalibrasi dalam penyamaan waktu satuan usaha (O'Brien et al., 2003). Lebih sederhana dapat ditulis sebagai:

$$
E R=\frac{\sum f}{\sum d} 100
$$

ER : Tingkat perjumpaan

$\Sigma \mathrm{f}$ : Jumlah total foto yang diperoleh

$\Sigma \mathrm{d}$ : Jumlah total hari operasi kamera

Analisis yang digunakan yaitu analisis deskriptif. Menurut (Sugiyono, 2005) analisis yang dilakukan deskriptif adalah analisis yang dilakukan untuk menilai sebuah data tanpa membuat perbandingan dengan data yang lainnya sehingga kesimpulan yang dibuat dapat memberikan gambaran utuh mengenai data yang telah disajikan.

\section{Hasil dan Pembahasan}

Salah satu cagar alam yang memiliki tipe hutan hujan tropis dataran rendah yang masih tersisa di pulau Jawa adalah Cagar Alam Nusakambangan Timur (CANT). Pengelolaannya berada di bawah Seksi Konservasi Wilayah II Pemalang, BKSDA Jawa Tengah. Kawasan tersebut ditunjuk sebagai cagar alam dengan tujuan sebagai monumen alam karena di Nusakambangan Timur kaya akan flora dan fauna yang merupakan perwakilan hutan hujan tropis dataran rendah. Surat Keputusan (Besluit) Gubernur Jenderal Hindia Belanda No. 26 Staatsblad No. 382 tanggal 24 Juli 1923 menjadi awal sejarah lahirnya CANT. Pada perjalanannya kemudian pemerintah Republik Indonesia melalui Kementerian kehutanan dan Perkebunan melakukan penunjukan kawasan tersebut menjadi Cagar Alam melalui Surat Keputusan (SK) No. 359/ Menhut-II /2004 tanggal 1 Oktober 2004 tentang Perubahan Keputusan Menteri Kehutanan dan Perkebunan Nomor 435/KPTS-II/1999 Tanggal 15 Juni 1999 tentang Penunjukan Kawasan Hutan di Wilayah Provinsi Jawa Tengah. Surat keputusan tersebut menegaskan keberadaan CANT dengan luas 277 ha. Selanjutnya melalui SK Menhut No. SK.2997/Menhut-VII/KUH/2014 tanggal 17 April 2014 negara menetapkan CANT dengan luasan 210,9 ha.

CANT secara administrasi masuk dalam wilayah Kelurahan Tambakreja Kecamatan Cilacap Selatan Kabupaten Cilacap Provinsi Jawa Tengah. Berdasarkan posisis geografis Cagar Alam Nusakambangan Timur terletak pada koordinat $7^{\circ} 45^{\prime} 35^{\prime \prime}$ sampai dengan $7^{\circ} 46^{\prime} 49^{\prime \prime}$ LS serta $109^{\circ} 1^{\prime} 57^{\prime \prime}$ dan $109^{\circ} 3^{\prime} 1^{\prime \prime}$ BT. Batas-batas kawasan Cagar Alam Nusakambangan Timur di sebelah utara Samudra Hindia dan Selat Segara Anakan, sebelah selatan Samudra Hindia/ Indonesia, sebelah barat hutan yang dikelola Kemenkumham dan sebelah timur Samudra Hindia/Indonesia.

Monitoring P.p. melas yang dilaksanakan kali ini merupakan pemanenan kamera trap yang dipasang pada bulan Juli 2020 atau bulan setelah kamera dipasang pada lokasi (gambar 1). Pada pemanenan kali ini mendapatkan 6 video P.p. melas, 15 video babi hutan (Sus scrofa) (gambar 5), 1 video kancil (Tragulus javanicus) (gambar 4), 2 video tupai gunung (Tupaia montana) (gambar 2), 1 video tikus (Apodemus sp.) (gambar 3), 20 video aktivitas manusia, dan 
Gambar 2, 3, 4, 5, dan 6

Tupai (Tupaia Montana), tikus (Apodemus sp.), kancil (Tragulus javanicus), babi hutan (Sus sucrofa) dan macan tutul
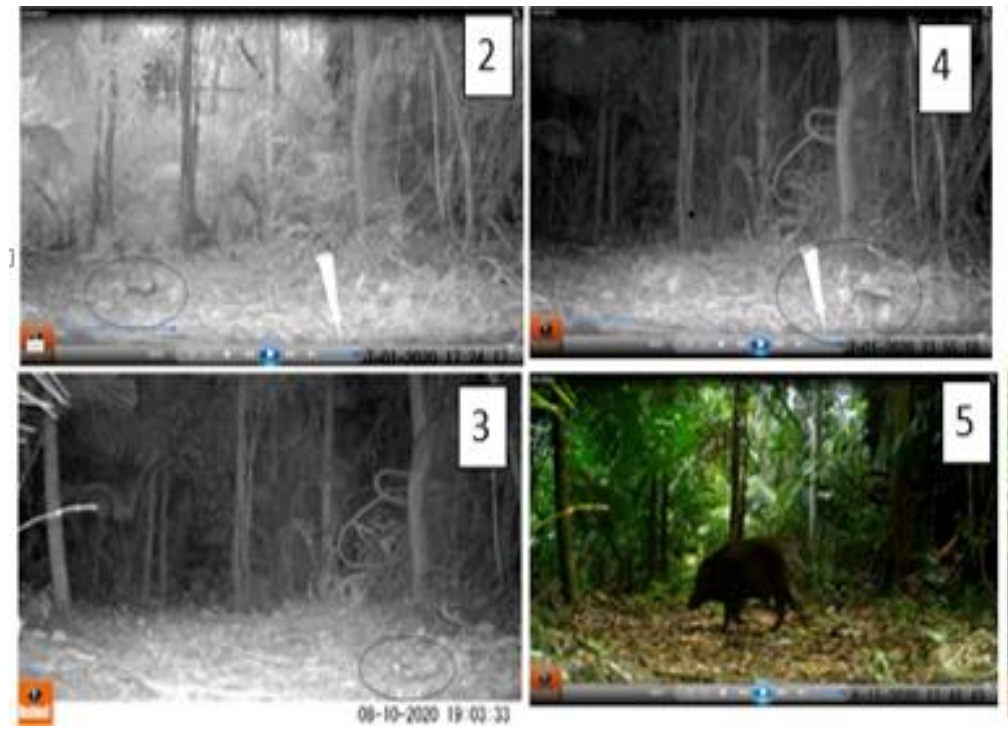

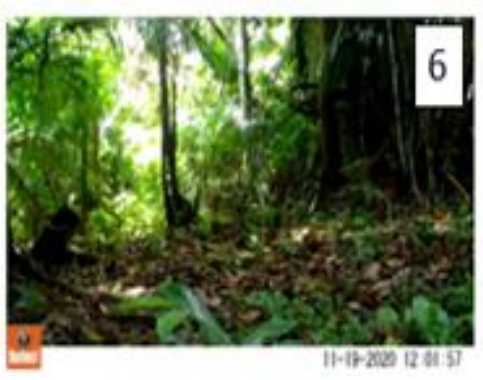

47 video non detection. Sementara itu individu P.p. melas yang berhasil tertangkap kamera yaitu 4 foto (gambar 6) P.p. melas dalam fase melanisme (dikenal sebagai macan kumbang) dan 2 foto P.p. melas dalam kondisi fase terang-macan tutul (Gambar 7). Hasil tangkapan kamera menunjukkan bahwa kawasan Cagar Alam Nusakambangan Timur masih terdapat satwa liar pakan P.p. melas. Menurut (Rustiadi, 2015) kehadiran P. p. melas di suatu habitat sangat terkait dengan kondisi dan kesesuaian habitat tersebut. Tangkapan kamera menunjukkan 4 jenis satwa lain. selain P.p. melas yaitu; Tupai, Tikus hutan, Kancil dan Babi hutan. Babi hutan mendominasi jumlah foto satwa liar selain P.p. melas dengan 16 buah foto. Berturut turut Tupai dengan 2 buah foto dan tikus serta kancil masingmasing 1 foto. foto. Meski belum bisa dihitung keanekaragaman dan keragaman satwa liar lain yang berpotensi sebagai pakan Nusakambangan Timur masih cukup tersedia pakan bagi hidup P.p. melas. Jenis satwa dan jumlah foto yang tertangkap oleh kamera trap dapat dilihat seperti tabel 1. Foto P.p. melas yang didapat sebanyak 6 buah. Foto tersebut 2 buah didapatkan pagi hari sebelum jam 5 pagi dan selebihnya didapatkan siang hari jam 09.00-16.00 WIB. Menurut (Lynam et al., 2007). analisis pergerakan P. p. melas didasarkan atas metadata yang ada dalam foto dan dikelompokkan menjadi 2 yaitu diurnal dan Nokturnal. Diurnal ditunjukkan dengan pergerakan P. p. melas pada siang hari yaitu pukul 06.00 - 18.00 wib dan nocturnal untuk pergerakan $P . p$. melas dalam kurun waktu antara $18.00-06.00$ WIB. Sehingga pola waktu pergerakan P. $p$. melas di CANT menunjukkan diurnal sebanyak $66 \%$ dan selebihnya melakukan aktivitas nokturnal (15\%). Hal tersebut sejalan dengan hasil penelitian (Rustiadi, 2015) bahwa satwa mangsa macan tutul aktivitas pola lebih banyak diurnal dari pada nocturnal. Bukti fisik kehadiran P.p. melas selain foto yaitu dengan ditemukannya feses. 
Budi Santoso, Wahyono Restanto

Tabel 1

Jenis satwa dan jumlah tangkapan foto satwa selain P.p. melas di Cagar Alam Nusakambangan Timur.

\begin{tabular}{cllcc}
\hline $\begin{array}{c}\text { No. } \\
\text { (Number) }\end{array}$ & \multicolumn{1}{c}{$\begin{array}{c}\text { Nama Latin } \\
\text { (Latin Name) }\end{array}$} & $\begin{array}{c}\text { Nama lokal } \\
\text { (Local Name) }\end{array}$ & $\begin{array}{c}\text { Jumlah Foto } \\
\text { (Number of Photo) }\end{array}$ & $\begin{array}{c}\text { Status } \\
\text { (Status) }\end{array}$ \\
\hline 1 & Sus scrofa & Babi hutan & 15 & TL \\
2 & Tupaia montana & Tupai & 2 & TL \\
3 & Tragulus javanicus & Kancil & 1 & TL \\
4 & Apodemus sp. & Tikus & 1 & TL \\
\hline
\end{tabular}

TL : Tidak dilindungi

\section{Gambar 7 dan 8}

Macan Tutul fase terang, Feces P. p melas
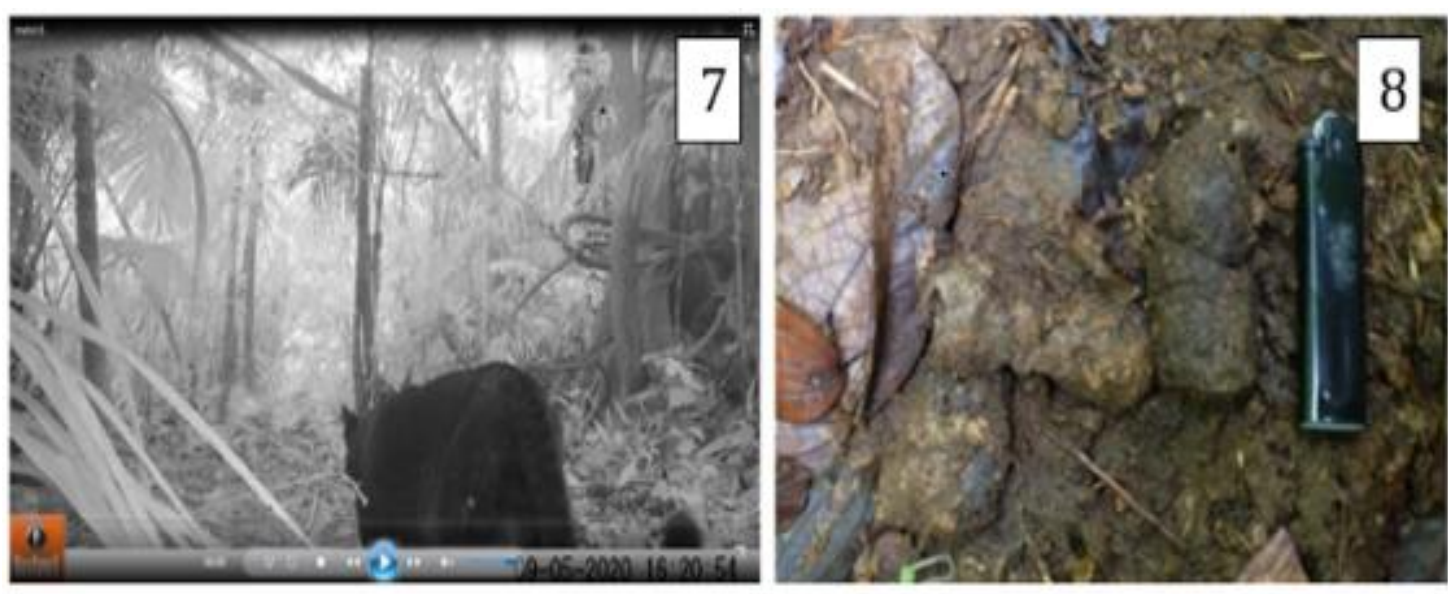

Pada sekitar lokasi pemasangan camera trap. Jumlah feses yang ditemukan ada di 2 titik dan menunjukkan kondisi masih basah (gambar 8). Sementara untuk bukti kehadiran yang lain yaitu jejak kaki dan cakaran di batang pohon tidak ditemukan. Berdasarkan tangkapan foto menunjukkan Babi hutan berpotensi menjadi pakan P. p. melas karena menunjukkan frekuensi kehadirannya tinggi di CANT. Menurut (Harahap \& Sakaguchi, 2003), P.p. melas menyukai beberapa jenis satwa salah satunya yaitu babi hutan (Sus scrofa) dan kehadirannya di CANT membuatnya menjadi pakan penting selain kancil dan tupai.
(Gunawan et al., 2012) menyebutkan bahwa kehadiran P.p. melas umumnya karena pada habitat tersebut selain ada air juga terdapat satwa pakannya berupa primata, dan ungulata. Dalam hal ini Kancil (Tragulus javanicus) dan Tupai (Tupaia montana). Menurut (Gunawan \& Sihombing, 2017). kehadiran P.p. melas dalam suatu habitat sangat tergantung dengan tutupan lahan, fungsi, topografi dan elevasi dari habitat tersebut. Preferensi tersebut ini diduga kuat sangat berhubungan dengan ketersediaan mangsa dan tingkat gangguan terhadap habitatnya. Sejalan dengan pendapat tersebut memang diperkirakan keberadaannya ada disana. 
Sementara itu menurut (Farida et al., 2003) kehadiran Kancil di habitatnya karena kancil menyukai buah-buahan yang mudah dicerna, dedaunan yang berair dan bijibijian. Oleh sebab itu, menurut (Wibisono et al., 2018), kancil digolongkan ke dalam kelompok satwa peranggas (browser/ concentrate selector).

Hasil perhitungan Encounter Rate menunjukkan hasil P.p. melas 4,44/100 hari; babi hutan 11,85/100 hari; Tupai 1,48/100 hari; tikus dan kancil masing-masing 0,74/100 hari. Kehadiran babi hutan di lokasi pengamatan cukup dominan. Namun hal tersebut tidak selalu berkorelasi dengan kehadiran P. p. melas. Menurut (Gunawan \& Alikodra, 2013) hal tersebut karena P. $p$. melas tidak melakukan perburuan untuk kebutuhan pakannya setiap waktu. Interval rata-rata pemangsaan P. p. melas berkisar 713 hari. Nilai kehadiran Babi hutan (ER tinggi) kemungkinan disebabkan karena foto berurutan satu individu. Hal ini ditunjukkan dengan terekamnya babi hutan dalam kurun waktu kurang dari 1 jam. Hasil tangkapan foto juga menunjukkan bahwa kehadiran Babi hutan paling sering muncul pada bulan Agustus dengan jarak waktu foto yang beriringan.

Sementara itu rona lingkungan di sekitar lokasi pemasangan kamera terlihat cukup teduh. Berbagai jenis tumbuhan baik berupa pohon besar maupun herba serta liana ada. Berdasarkan identifikasi vegetasi di lokasi sekitar didapatkan 23 jenis tumbuhan yang berasal dari 18 famili (tabel 2). Beberapa diantaranya merupakan tumbuhan pakan bagi Tupai, Tikus hutan dan kancil.

Menurut (Balai Konservasi Sumber Daya Alam Jawa Tengah, 2017) kondisi keanekaragaman hayati di Cagar Alam Nusakambangan Timur menunjukkan kondisi tutupan vegetasi yang utuh dan rapat serta terdapatnya beberapa jenis flora dan fauna yang termasuk jenis langka dan dilindungi. Hasil inventarisasi flora menunjukkan terdapat 51 jenis tingkat pohon, tingkat tiang 30 jenis, tingkat pancang 37 jenis dan tingkat semai 54 jenis.

Menurut (Balme et al., 2007) catchability mangsa P. p. melas tidak selalu korelatif dengan tingginya tutupan habitat. Kondisi Tutupan habitat sedang lebih disukai oleh P.p. melas untuk berburu dan menangkap mangsanya. Tingginya tingkat tutupan lahan menjadi semacam penghalang bagi P. p. melas untuk mendeteksi keberadaan mangsanya. Setidaknya dalam kurun waktu 5 bulan terakhir telah tertangkap kamera sebanyak 20 aktivitas manusia di lokasi yang menjadi habitat P.p. melas. Aktivitas manusia tersebut semuanya dilakukan secara berkelompok mulai 3 sampai 6 orang.

Enam buah foto berasal dari mahasiswa praktikum yang didampingi petugas dan selebihnya 14 buah foto berasal dari aktivitas masyarakat umum. (Elmhagen \& Rushton, 2007) menyebutkan bahwa satwa jenis karnivora dapat memainkan top down control dalam sebuah habitat, sehingga berpotensi merubah struktur relung dalam sebuah ekosistem. Hal tersebut senada dengan (Balme et al., 2007) bahwa kehadiran karnivora besar dapat menjadi spesies paying dalam prakondisi sebuah kawasan konservasi. Hal tersebut mengingat karnivora besar memerlukan luasan habitat yang memadai untuk dapat bertahan hidup dengan baik. Dengan demikian kehadiran karnivora besar dapat dipastikan akan mendorong spesies lain berkembang dengan baik. Menurut (Kusmawanto \& Imron, 2018), menyebutkan bahwa P.p. melas merupakan satwa liar yang mampu menyesuaikan diri terhadap aktivitas manusia. Meskipun 
Budi Santoso, Wahyono Restanto

Tabel 2

Jenis vegetasi yang ada di sekitar lokasi camera trap

\begin{tabular}{clll}
\hline No. & Nama Latin & Nama lokal & Famili \\
\hline 1 & Actinodaphne glomerata & Wuru Dapung & Lauraceae \\
2 & Ardisia elliptica & Lampeni & Primulaceae \\
3 & Arenga obtusifolia & Langkap & Arecaceae \\
4 & Artocarpus elasticus & Benda & Moraceae \\
& & & Anacardiacea \\
5 & Buchanania arborescens & Poh-Pohan & e \\
6 & Calamus sp & Rotan & Arecaceae \\
7 & Cananga odorata & Kenanga Hutan & Annonaceae \\
8 & Canarium hirsutum & Kenari Hutan & Burseraceae \\
9 & Clausena excavata & Tikusan & Rutaceae \\
10 & Cratoxylum formosum & Geronggang & Hypericaceae \\
11 & Dillenia obovata & Simpur & Dilleniaceae \\
12 & Ficus septica & Awar-awar & Moraceae \\
13 & Flacourtia rukam Zoll. \& Mor. & Rukem & Salicaceae \\
14 & Ixora sp & Soka alas & Rubiaceae \\
15 & Laportea sinuata & Kemadu & Urticaceae \\
& & & Euphorbiacea \\
16 & Mallotus philippensis (Lam.) Müll.Arg. & Kangkejuan & e \\
17 & Pterospermum javanicum & Bayur & Malvaceae \\
18 & Saurauia javanica & Umbel-Umbelan & Actinidiaceae \\
& & & Anacardiacea \\
19 & Spondia pinnata & Dondong Alas & e \\
20 & Sterculia macrophylla & Hantap & Malvaceae \\
21 & Villebrunea rubescens. & Jurang & Urticaceae \\
22 & Xanthophyllum excelsum (Blume) Miq. & Ndog-dogan & Polygalaceae \\
23 & Ziziphus sp & Bidara alas & Rhamnaceae \\
\hline & & &
\end{tabular}

begitu, pencegahan fragmentasi habitat dan pengendalian aktivitas manusia tetap perlu dilakukan sebagai upaya konservasi Macan Tutul Jawa di Pulau Nusakambangan

Menurut (Gunawan \& Alikodra, 2013), home range P. p. melas jantan meliputi 6-63 $\mathrm{km} 2$, sementara itu P. p. melas betina memiliki home range antara 6-13 km2. Berdasar informasi tersebut CANT memiliki luas yang sangat memadai sebagai habitat $P$. p. melas. BKSDA Jateng selaku pengelola kawasan ini dapat mempertahankan kondusifitas habitat antara lain melalui manajemen habitat dengan lebih baik lagi. Salah satunya melalui pelaksanaan pengendalian aktivitas masyarakat dalam bentuk apapun ke dalam CANT serta patroli hutan yang lebih intensif.

\section{Kesimpulan}

Didapatkan 97 video yang terbagi dalam 6 video P.p. melas, 15 video babi hutan (Sus scrofa), 1 video kancil (Tragulusjavanicus), 2 video tupai gunung (Tupaia montana), 1 video tikus (Apodemus sp.) 20 video aktivitas 
manusia, dan 47 video non detection. Hasil perhitungan Encounter Rate menunjukkan hasil P.p. melas 4,44/100 hari; babi hutan 11,85/100 hari; Tupai 1,48/100 hari; tikus dan kancil masing-masing 0,74/100 hari. Sementara itu untuk jejak keberadaan P.p. melas ditemukan 2 kotoran.

\section{Ucapan Terima Kasih}

Terima kasih untuk kawan-kawan BKSDA Jateng terutama di Resort Konservasi Wilayah Cilacap, Seksi Konservasi Wilayah II Pemalang.

\section{Daftar Pustaka}

Balai Konservasi Sumber Daya Alam Jawa Tengah. (2017). Inventarisasi Potensi CA Nusakambangan Timur dalam Rangka Evaluasi Fungsi.

Balme, G., Hunter, L., \& Slotow, R. (2007). Feeding habitat selection by hunting leopards Panthera pardus in a woodland savanna: prey catchability versus abundance. Animal Behaviour, 74(3), 589-598. https://doi.org/10.1016/j.anbehav.20 06.12.014

Elmhagen, B., \& Rushton, S. P. (2007). Trophic Control of Mesopredators in Terrestrial Ecosystems: Top-down or Bottom-up? Ecol Lett. https://doi.org/10.1111/j.14610248.2006.01010.x

Farida, W. R., Setyorini, L. E., \& Sumaatmadja, G. (2003). Habitat distribution and diversity of forest plant as feed resources of mouse deer (Tragulus javanicus) and barking deer (Muntiacus muntjak) in Nature Preserve of west and east Nusakambangan. Biodiversitas Journal of Biological Diversity, 4(2), 97-102. https://doi.org/10.13057/biodiv/d04 0206

Gunawan, H., \& Alikodra, H. S. (2013).
Bioekologi dan Konservasi. Puslitbang Konservasi dan Rehabilitasi - Badan Penelitian dan Pengembangan Kehutanan.

Gunawan, H., Prasetyo, L. B., Mardiastuti, A., \& Kartono, A. P. (2012). Habitat Macan Tutul Jawa (Panthera pardus melas Cuvier 1809) di Lansekap Hutan Tanaman Pinus (Habitat of Javan Leopard (Panthera pardus melas Cuvier 1809) in Pine Plantation Forest Landscape. Pusat Litbang Konservasi Dan Rehabilitasi, 9(1), 49-67.

Gunawan, H., \& Sihombing, V. S. (2017). Preferensi Habitat Macan Tutul Jawa (Panthera pardus melas Cuvier 1809) di Jawa Bagian Barat. Jurnal Penelitian Hutan Dan Konservasi Alam, 14(1), 35-44.

https://doi.org/10.20886/jphka.2017 .14.1.35-44

Harahap, S. A., \& Sakaguchi, N. (2003). Monitoring research on leopard (Panthera pardus) in Cikaniki Area, Gunung Halimun National Park. Research on Endangered Species in GHNP. Research and Biodiversity of Conservation in Indonesia, XI, 2-19.

Kementerian LHK. (2016). Strategi dan Rencana Aksi Konservasi Macan Tutul Jawa 2016 - 2026. Kementerian LHK.

Kusmawanto, A., \& Imron, M. A. (2018). Hubungan Antara Aktifitas manusia dan Distribusi Macan Tutul jawa (Panthera pardus melas Cuvier, 1809) di Pulau Nusakambangan. Universitas Gajah mada.

Lynam, A. J., Laidlaw, R., Wan Noordin, W. S., Elagupillay, S., \& Bennett, E. L. (2007). Assessing the conservation status of the tiger Panthera tigris at priority sites in Peninsular Malaysia. Oryx, 41(4), 454-462. https://doi.org/10.1017/S00306053 07001019 
Maharadatunkamsi, Phadmacanty, N. luh P. R., Sulistyadi, E., Inayah, N., Achmadi, A. S., Dwijayanti, E., Semiadi, G., Farida, W. R., Wirdateti, Wiantoro, S., Nugraha, R. T. P., Fitriana, Y. S., \& Kurnianingsih. (2020). Status Konservasi dan Peran Mamalia di Pulau jawa (T. D. Aprianita (ed.); October 20). LIPI. https://eservice.lipipress.lipi.go.id/press/catal og/view/290/248/704-3

O’Brien, T. G., Kinnaird, M. F., \& Wibisono, H. T. (2003). Crouching Tigers, Hidden Prey: Sumatran Tiger and Prey Population in a Tropical Forest landscape. Animal Conservation, 6(2), 131-139. https://doi.org/S1367943003003172

O'Connell, A. F., Nichols, J. D., \& Karanth, K. U. (2011). Camera traps in animal ecology: Methods and analyses. In Camera Traps in Animal Ecology: Methods and Analyses (Issue January 2011). https://doi.org/10.1007/9784-431-99495-4

Rustiadi, A. (2015). Macan tutul Jawa (Panthera pardus melas Cuvier, 1809) dan mangsa potensialnya di Bodogol, Taman Nasional Gunung Gede Pangrango. 1(7), 236-241. https://doi. org/10.13057/psnmbi/m010211

Stein, A. B., Athreya, V., Gerngross, P., Balme, G. A., Henschel, P., Karanth, K. U.,
Miquelle, D., Rostro-Garcia, S., Kamler, J. F., Laguardia, A., Khorozyan, I., \& Ghoddousi, A. (2016). Panthera pardus. The IUCN Red List of Threatened Species 2016. The IUCN Red List of Threatened Species, 8235(January),

e.T15954A102421779.

http://www.iucnredlist.org/details/1 $\underline{5954 / 0}$

Sugiyono. (2005). Statistik Untuk Penelitian. Alfabeta.

Wibisono, H. T., Wahyudi, H. A., Wilianto, E., Romaria Pinondang, I. M., Primajati, M., Liswanto, D., \& Linkie, M. (2018). Identifying priority conservation landscapes and actions for the Critically Endangered Javan leopard in Indonesia: Conserving the last large carnivore in Java Island. PLoS ONE, 13(6), 1-13. https://doi.org/10.1371/journal.pone .0198369

Wilting, A., Patel, R., Pseftorf, H., Kern, C., Sultan, K., Ario, A., Penaloza, F., KramerSchadt, S., Radchuk, V., Foerster, D. W., \& Fickel, J. (2016). Evolutionary history and conservation significance of the Javan leopard Panthera pardus melas. Journal of Zoology, 299(4), 239-250. https://doi.org/10.1111/jzo.12348 